\title{
The role of reliable mining and construction analysis in adjudicating mining damage claims
}

\author{
Wojciech Kocot \\ Faculty of Mining Surveying and Environmental Engineering; \\ AGH University of Science and Technology; 30 Mickiewicza Av., 30-059 Krakow, Poland; \\ wokocot@agh.edu.pl (D)0000-0002-9408-1985
}

\begin{abstract}
The basis for recognising claims for mining damage to a structure should be a mining and construction analysis, carried out following a detailed visual inspection of the damage and the results of surface deformation measurements. It allows to establish a cause and effect relation between the activity of the mining company and the damage. Unfortunately, there are cases when such an analysis is omitted and the following scheme is used: "since there is damage and the object is located in a mining area, it is mining damage". The problem is illustrated by two court cases where the author acted as an expert witness. Both cases are examples of the so-called pseudo-mining damage and confirm the thesis that the mere image of damage without professional analysis of construction and mining factors may lead to wrong conclusions regarding the causes of the damage.
\end{abstract}

Keywords: mining damage, mining influences, pseudo-mining damage

\section{Introduction}

Underground mining exploitation often leads to damage to building structures located on the surface. According to the provisions of the Geological and Mining Law [9], [10], the mining company is obliged to repair the damage caused by its mining operations. On this basis, owners of building structures often make claims to mining companies for repair of damages. However, the basis for recognising such claims should always be a mining and construction analysis, based on the results of surface deformation measurements and detailed visual inspection of the damage. This makes it possible to establish a causal link between the mining plant's activity and the damage. It is necessary, as in many cases the causes of damage are completely different and have nothing to do with the revealed mining influence. Unfortunately, there are cases in which such an analysis is omitted and the following scheme is followed: "since there is damage and the object is located in a mining area, it is a mining damage".

The author was inspired to write this article by numerous court cases in which he acted as an expert witness. Two of them are briefly presented to illustrate the problem. 


\section{Example one - single-family residential building}

\subsection{Description of the building structure}

This building (Fig. 1) was constructed in stages. In 1953, the oldest part of the building, indicated in Fig. 2 with the letter A, was erected. It is a single-storey building with a usable attic, completely cellared, founded on concrete footings. The basement walls were built of quarry stone and the walls of the ground floor of ceramic brick with cement-lime mortar. The floor above the basement and the ground floor was made of concrete, poured between steel beams, without rims. At the end of the 1960s, a single-storey kitchen and sanitary facility was added to the eastern side of the building at the same level (Fig. 2, letter B). The extension was made without expansion joints, with a connection to the existing part of the building and using its eastern wall. The building was given its final form in 1975, when a staircase (Fig. 2, letter C) and one storey were added. The decision to grant permission for the extension stipulated that the building had to be protected against "category III mining damage". The staircase received its own reinforced concrete footings and masonry basement walls separated from the rest of the building. However, the expansion joint was terminated at the basement floor level. Higher up, staircase $\mathrm{C}$ shares a common wall with part $\mathrm{A}$. The walls of the staircase and the entire superstructure of part A were built using self-made cinder blocks. The non-extended part B is used as a terrace. A common, monolithic, cross-reinforced concrete floor above the first floor was made for both parts (A and $\mathrm{C}$ ). Insulation and an appropriate slope of the ceiling were obtained by laying a layer of granulated slag on it, followed by suprema and cement screed. The roof was covered with layers of roofing paper on bitumen.

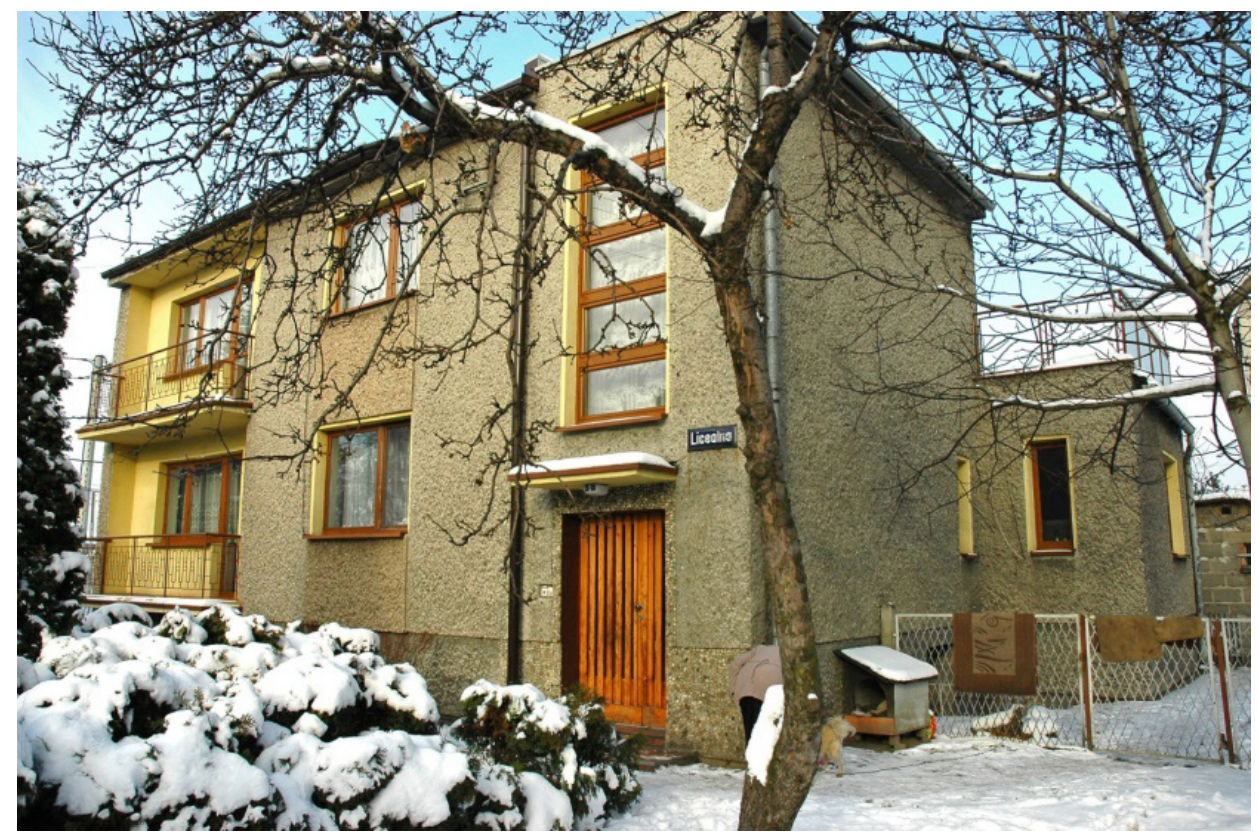

Fig. 1. View of the building from the south-east. Source: author 


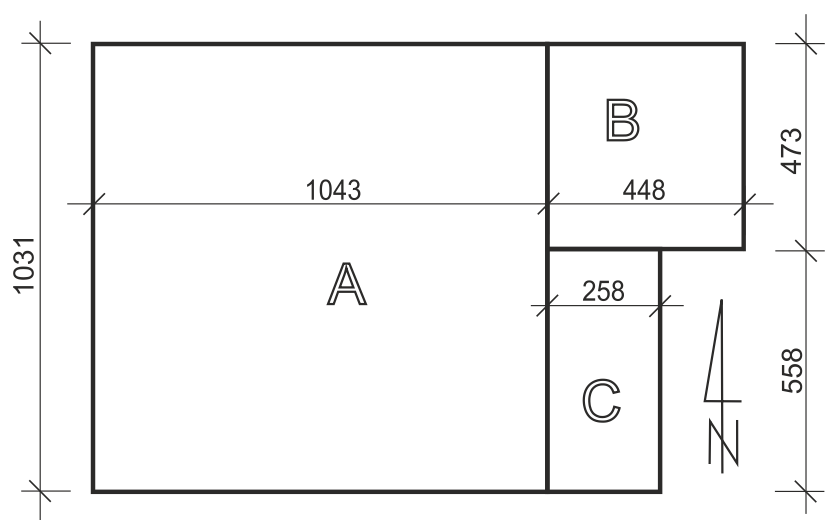

Fig. 2. Individual stages of building erection. Source: author

During the expansion of the building, a number of mistakes were made, both in the design and execution of the works. One of the most important errors was the way in which the new parts were connected with the existing ones. The rules of the art of construction recommend in such cases a complete decoupling of the added part. This becomes particularly important when the building is located in a mining area. In the analysed case, in the lower parts of the building (at the basement level) the added staircase was isolated, but the higher parts (the ground floor and the ground floor) were connected with the existing part. This solution makes the building structure very sensitive to the influence of horizontal tensile deformations and curvature of the terrain. The lower parts of the staircase may "move away" from the building, while its upper part remains united with it. This can lead to serious damage in the area of contact. Another design error was the abandonment of the ceiling rim of the superstructure storey. On the other hand, the continuous perimeter ceiling rim above the ground floor was abandoned at the stage of execution works. Although this ring was designed, its absence is proved by the presence of a large window above the entrance to the building (visible in Fig. 1).

In conclusion, it should be emphasised that the adopted construction solutions and mistakes made during construction caused that the actual resistance to mining influence of the extended building is far lower than indicated in the permit for extension.

\subsection{Damage pattern and probable causes}

During the on-site inspection, no damage that could pose a threat to building safety was noticed. However, all damages reported by the Owner were found to exist. The most significant were the following:

- a vertical crack visible on the northern wall, up to $5 \mathrm{~mm}$ in diameter, at the junction of the added part B with the main body of the building (Fig. 3),

- a $2 \mathrm{~mm}$ crack at the junction of the extended staircase $\mathrm{C}$ with the main body of the building,

- vertical and diagonal scratches and cracks up to $1.5 \mathrm{~mm}$ in lintels or at the corners of ground floor and basement window openings (e.g. Fig. 4), 
- horizontal cracks and fissures in the walls up to $2 \mathrm{~mm}$ in size in the area of the reinforced concrete floor slab (e.g. Fig. 5),

- horizontal crack up to $1 \mathrm{~mm}$ in size between the ceiling and the wall separating the south-west room from the north-west room and a diagonal crack below (e.g. Fig. 6),

- in the basement, longitudinal cracks in the ceiling plaster, up to $1.5 \mathrm{~mm}$ in size, in the course corresponding to the layout of the steel ceiling joists.

The presented image of the damage indicated that its causes should be sought primarily among constructional factors, including those associated with the history of the extension. Thus, the first two described cracks were caused by the separation of the added parts $\mathrm{B}$ and $\mathrm{C}$ from the main body of the building. When adding a new segment, one should always remember that the ground which is loaded with it will start to settle, while the process of settling under the building erected earlier is already finished. Therefore, an attempt to connect the walls of new segments with the old ones usually results in a spontaneous formation of a "dilation" by the structure. A larger gap opening at the top and a smaller one at the bottom corresponds to smaller settlements of the added block in the immediate vicinity of the existing one, where the ground is already compacted.

Vertical and diagonal cracks in lintels of ground floor and basement window openings were related to the technology of their construction. The appearance of cracks excluded the presence of reinforced concrete or steel lintels in the window part of the wall. Therefore, these were most probably flat brick lintels, particularly prone to cracking near the middle of the span. An additional factor was that the masonry over the windows was overloaded by the storey above. It is worth noting that similar cracks did not occur over the window openings of the first floor, where reinforced concrete lintels were made.

Cracks in the walls along the line of the flat roof slab are typical for the technology used. The cracks are formed mainly as an effect of slag degassing under the influence of frequent changes of humidity and temperature and as a result of thermal work of the flat roof slab. Similar damage is common in buildings with similar roofing throughout the country. The group of damages related to the execution technology also includes the observed cracks in the basement ceiling. All the cracks run along steel bearing beams hidden in concrete, which is typical for this type of construction.

The gap between the first floor interior wall and the ceiling was caused by a construction error. This wall, $25 \mathrm{~cm}$ thick, was erected with an offset of approx. $0.6 \mathrm{~m}$ from the corresponding wall on the ground floor. As the only support for this wall is the ceiling above the ground floor, the scratches and cracks occurring in it are connected with the deflection of this ceiling. 


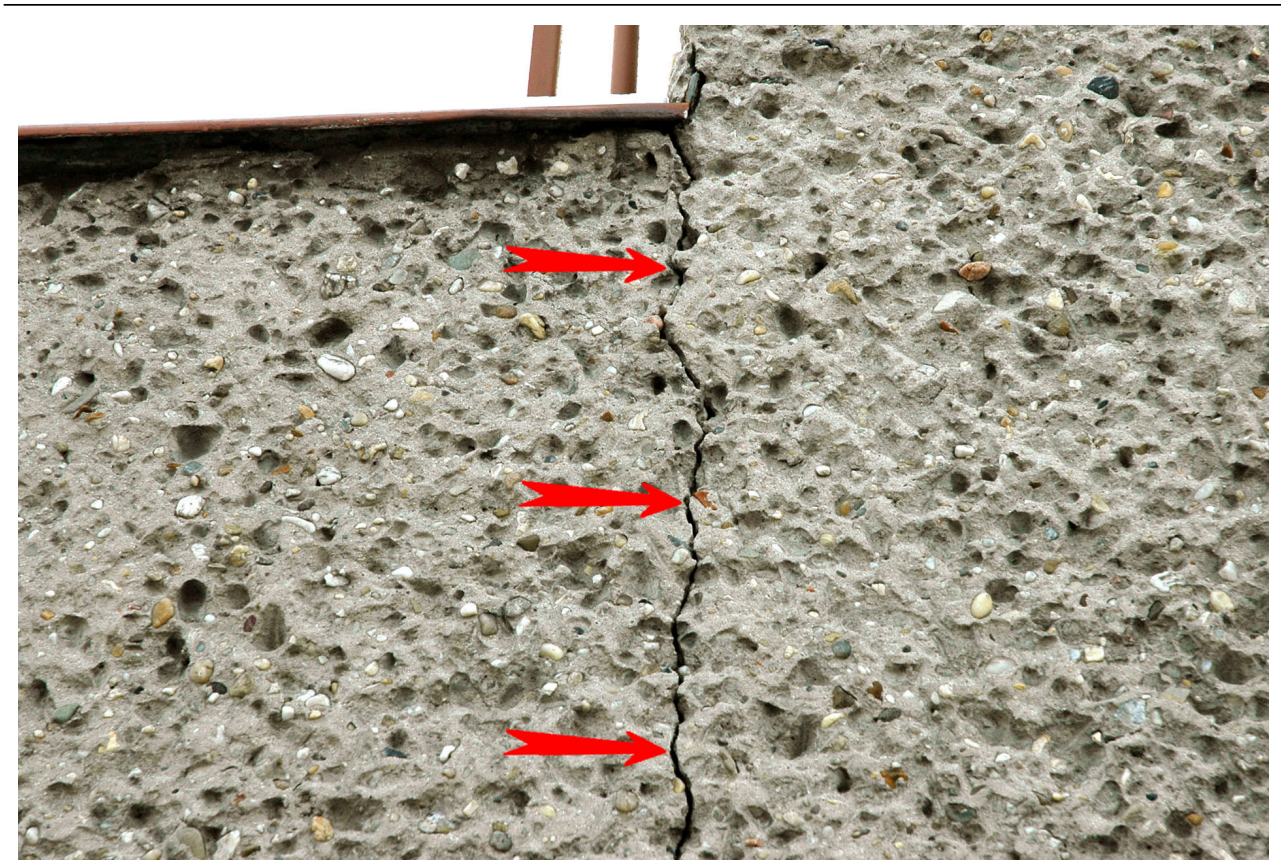

Fig. 3. Fragment of the northern wall - vertical crack at the junction of the extension $\mathrm{C}$ with the main body of the building. Source: author

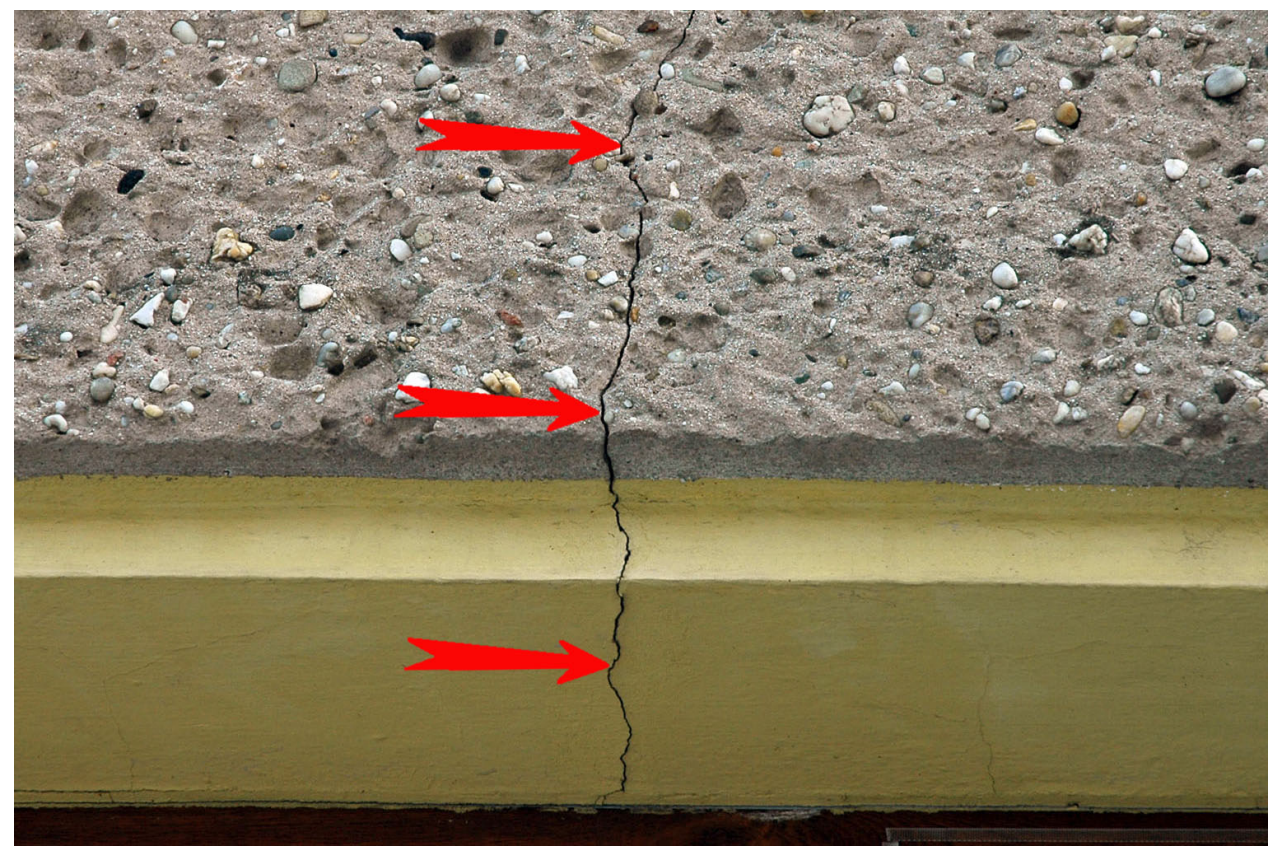

Fig. 4. Fragment of the western wall - vertical crack above ground floor window opening. Source: author 


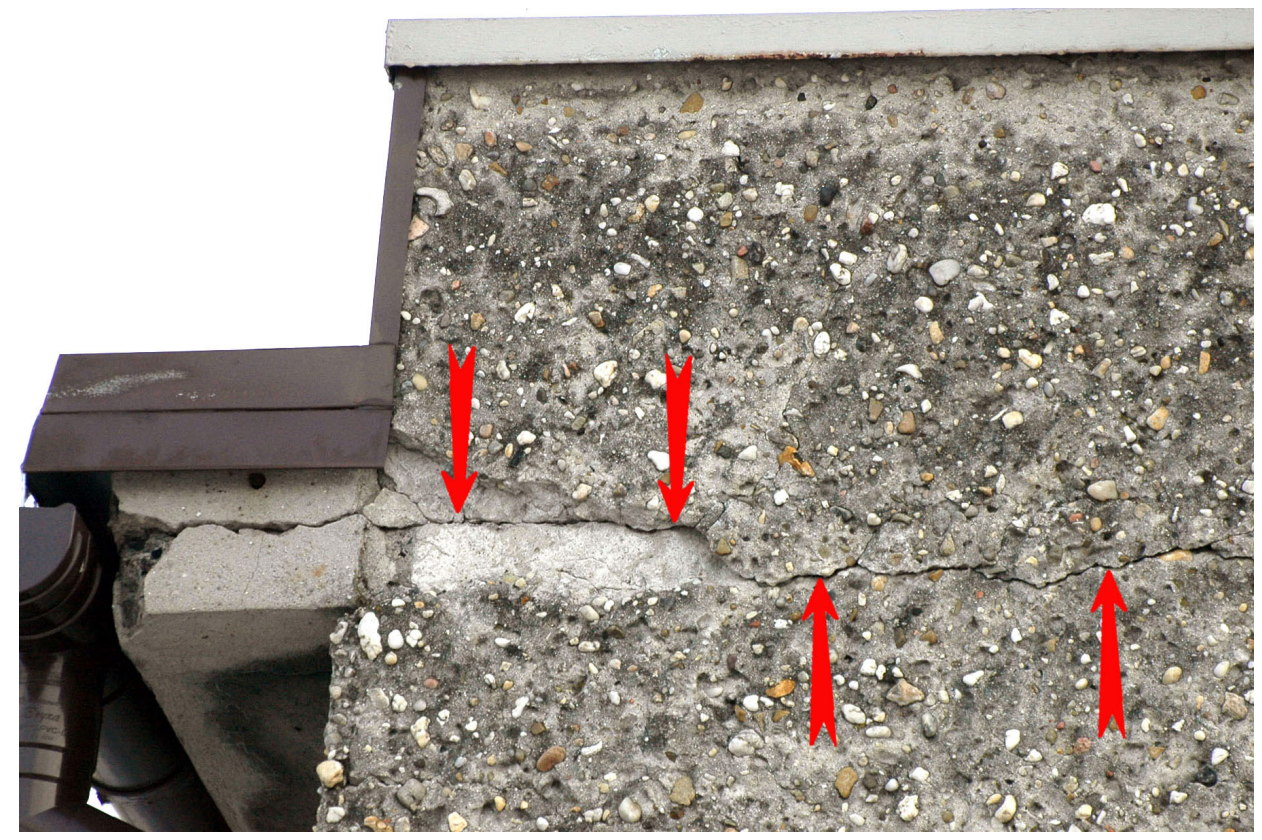

Fig. 5. Fragment of the western wall - visible horizontal cracks along the upper and lower surface of the ceiling slab. Source: author

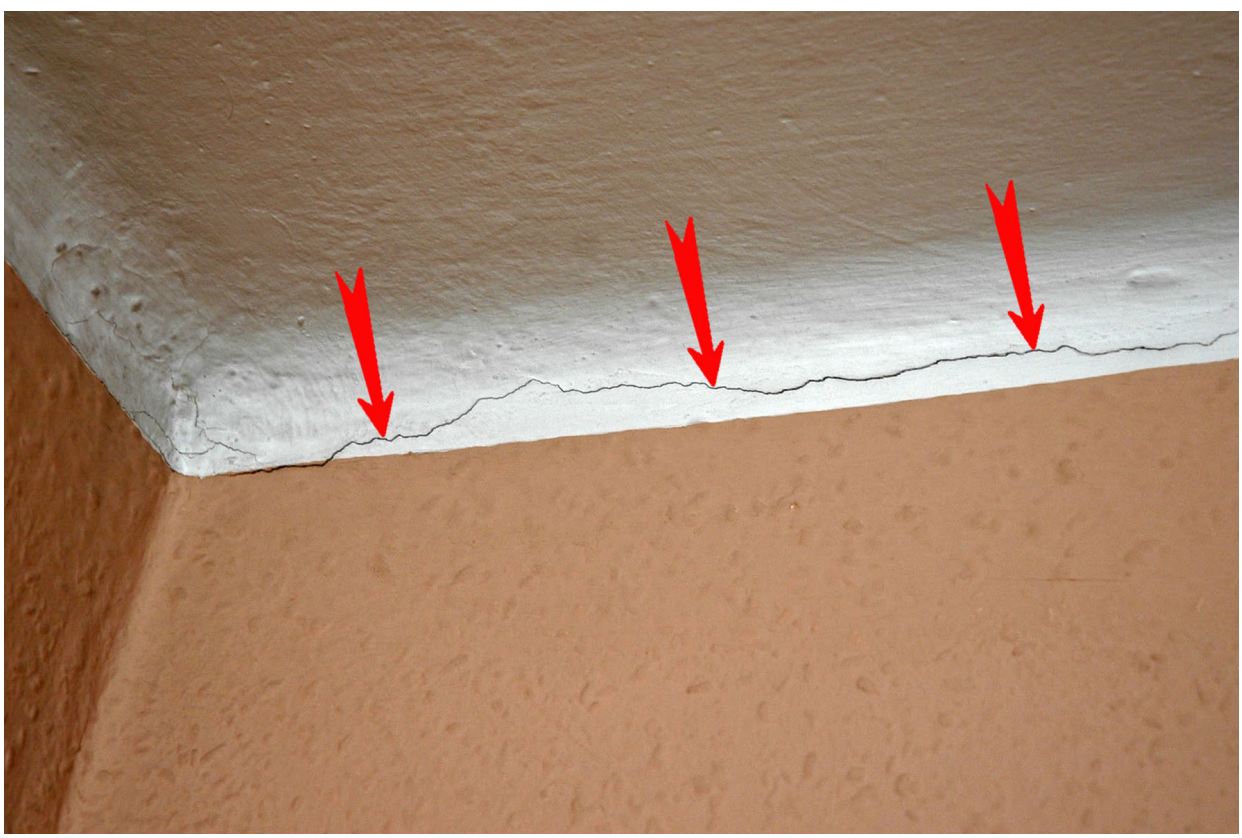

Fig. 6. Gap of up to $1.5 \mathrm{~mm}$ between ceiling and first floor interior wall. Source: author 


\subsection{Assessment of mining influences in the building area}

The analysis of the influence of continuous deformation showed that mining exploitation was carried out twice in the vicinity of the building in question. The first, at the average depth of $370 \mathrm{~m}$, passed about $400 \mathrm{~m}$ to the south of the building, and the second, at the average depth of $540 \mathrm{~m}$, passed about $900 \mathrm{~m}$ to the south-east of the building. The ground deformation indices obtained by means of the conducted calculations [1] turned out to be smaller than the limits for the zero category of the mining area. The area characterised by such small deformation indices is practically considered to be free from direct mining influences and therefore not dangerous.

In turn, the influence of discontinuous deformations on the building was excluded. Firstly, because they have not been observed in the analysed area so far, and secondly, because the image of damage which occurs under their influence is completely different from the observed one [3], [4].

Further analysis showed that at the location of the building the mining-induced para-seismic shocks were characterised by zero degree of intensity according to the GSI-GZW $\mathrm{KW}_{\mathrm{KW}}$ intensity scale or slightly exceeded it. At this point, it is worth mentioning the descriptive explanation of the degrees of intensity of para-seismic impacts on buildings according to the GSI-GZW $_{\mathrm{KW}}$ (e.g. [6], [7]):

- intensity degree 0 means that the parameters of vibrations from shaking are comparable to the level of vibrations caused by the technical usability of the object (e.g. slamming doors) - shaking does not cause any damage to buildings,

- intensity level 1 means that the vibration parameters of shocks are comparable to the seismic background - shocks do not cause damage to buildings. Shocks do not cause damage to buildings. At most, they may cause a small increase in pre-existing damage, e.g. a small increase in the opening of cracks.

Consequently, according to this explanation, there was practically no risk of damage to the building in question as a result of paraseismic tremors of mining origin. Therefore, the tremors could not have caused any damage to the building, but could only have slightly increased the extent of the damage.

In summary, due to the negligible extent of mining impacts, their influence on the damage to the building was practically excluded. At the same time, non-mining causes were identified in all cases.

It was clear at the court hearing to the lawyer representing the Owner that, since the building was located in a mining area and damage had occurred to it, it clearly had to be of mining origin. The author demonstrated to the court the absence of mining impacts capable of causing damage, and at the same time presented to the court the actual causes of the damage. Thus, he proved the absence of a causal link between the activity of the mining company and the damage caused to the building.

\section{Example two - an industrial building}

\subsection{Description of the building structure}

The second case concerned an industrial building erected in the early 1980s (Fig. 7). At the end of the 1990s, it changed ownership and was adapted for use by another manufacturing sector. It is a building with a complete basement, consisting of three structurally independent segments separated from each other (Fig. 8): 
- segment 1 (western) with axial dimensions of the horizontal projection of $30.0 \times 15.0 \mathrm{~m}$,

- segment 2 (central) of similar axial dimensions to the western one,

- segment 3 (eastern) with axial dimensions of the horizontal projection of $15.0 \times 15.0 \mathrm{~m}$.

The western segment, the central segment and the first $(6 \mathrm{~m})$ field of the eastern segment form the hall-like part of the building, approximately $13 \mathrm{~m}$ high. The remaining (eastern) part of segment 3, with axial dimensions of $9.0 \times 15.0 \mathrm{~m}$ is an $18.5 \mathrm{~m}$ high former silo for loose materials, currently not in use). The designed dilatation of all expansion joints is $10 \mathrm{~cm}$.

All segments have a reinforced concrete monolithic zero state. In the case of segments 1 and 2, the load-bearing structure consists of six transverse two-nave frames, longitudinally spaced at $6.0 \mathrm{~m}$, connected to each other by three longitudinal reinforced concrete walls and a ceiling made of TT-type prefabricated reinforced concrete elements. The transverse walls are partly reinforced concrete and partly brick. The first field of segment 3 (under its hall part) has a similar construction as the other two segments. In the remainder of segment 3 , the zero state is formed by monolithic reinforced concrete columns, spaced at $4.5 \times 3.0 \mathrm{~m}$, adapted to the steel support structure of the silos once placed on them. All three segments were placed on a reinforced concrete foundation grid.

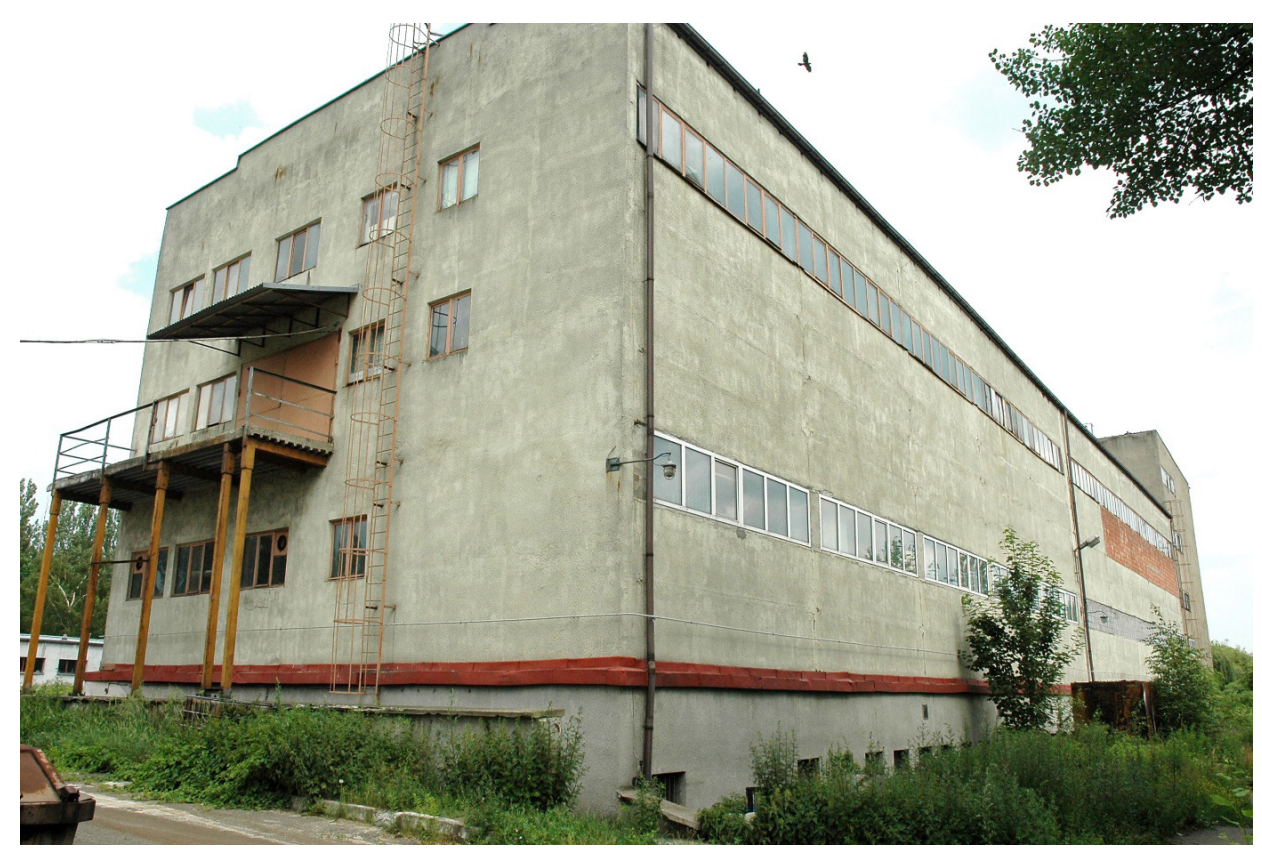

Fig. 7. The industrial building in question - view from the south-west. Source: author 


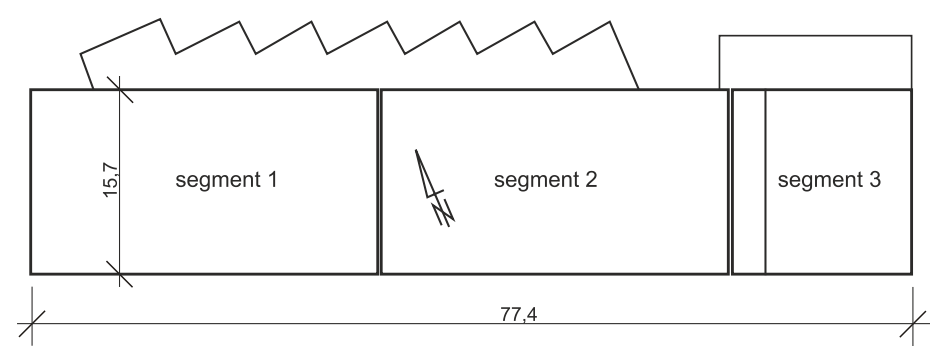

Fig. 8. The industrial building in question - segmentation

The overground part of the building has a steel skeleton load-bearing structure. In the case of segments 1 and 2 it is a two-storey hall with two naves $(7.5+7.5 \mathrm{~m})$ at the height of the first storey, changing into a single-nave hall $(15.0 \mathrm{~m})$ on the second storey. The ceiling of the first storey at the level of $+4.20 \mathrm{~m}$ was made of TT-type reinforced concrete prefabricated elements supported on steel beams. The roof of the hall is made of reinforced concrete pan slabs with a span of $6.0 \mathrm{~m}$ based on trussed roof girders. Stability in the longitudinal direction is provided by steel girders placed in one field of each segment. Lateral stability was achieved by restraining the columns in the ceiling above the basement. The internal cladding of the hall part consists of reinforced concrete prefabricated wall elements and partly of curtain walls made of siporex and ceramic blocks. The enclosure of the former silo consists of filling walls made of siporex blocks.

According to the opinion attached to the court file, the object was to be secured at the stage of construction against mining influences with indicators corresponding to category III of the mining area.

\subsection{Damage pattern and probable causes}

During the on-site inspection, no damage to the supporting structure of the building was observed. However, all damages reported by the Owner were found. The most significant damages included:

- cracks visible from the outside of the building on the basement walls,

- cracks in the partition walls,

- cracks and chipping of the plaster at the joints of prefabricated reinforced concrete elements of the above-ground walls,

- cracks in the floors.

At first glance, some of the damage appeared severe. These included numerous cracks visible from the outside on the part of the basement walls protruding above the ground surface. These cracks, mostly horizontal, occurred mainly in the vicinity of window openings and were 2-10 mm wide (e.g. Fig. 9). Larger cracks were sometimes accompanied by a few mm displacement of both parts of the wall in relation to each other in the crack plane. After thorough examination of the cracks, it turned out that only the brick wall pressing the foamed polystyrene insulation layer visible from the outside was cracked. No cracks or even minor scratches were visible anywhere on the reinforced concrete supporting wall on the inside. It should be noted that the ground deformations connected with mining exploitation cannot selectively affect only the finishing layer of the wall without damaging the load-bearing layer. The cause of the damage should therefore be sought among construction defects. In this case, it was a defective foundation of the wall pressing the insulation and the lack of its proper connection with the reinforced 
concrete basement wall. This diagnosis was further confirmed by the frequently occurring spalling and outward tilting of the part of the wall below the crack (e.g. Fig. 9).

In the southern part of segment 2 there were horizontal cracks in the basement partition walls $-12 \mathrm{~cm}$ thick brick (e.g. Fig. 10). The extent of the cracks sometimes exceeded $10 \mathrm{~mm}$, but decreased as they approached the load-bearing walls. According to the information obtained, these walls did not have a proper foundation - they were erected directly on the floor. The floor was laid on a layer of embankment created during the backfilling of foundations. This soil consolidated over time, and with it the floor and the partition walls settled, more in the middle, less in the vicinity of the load-bearing walls. This means that, in this case too, the cause of the damage was a construction defect.

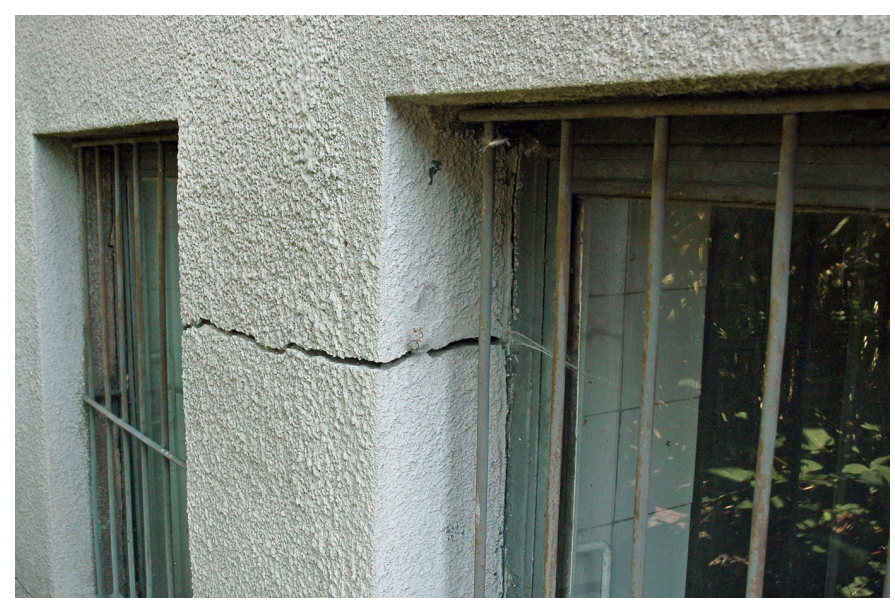

Fig. 9. Fragment of the basement wall of segment 1 - visible cracks in the inter-window pillar from the outside and no damage at this point inside. Source: author

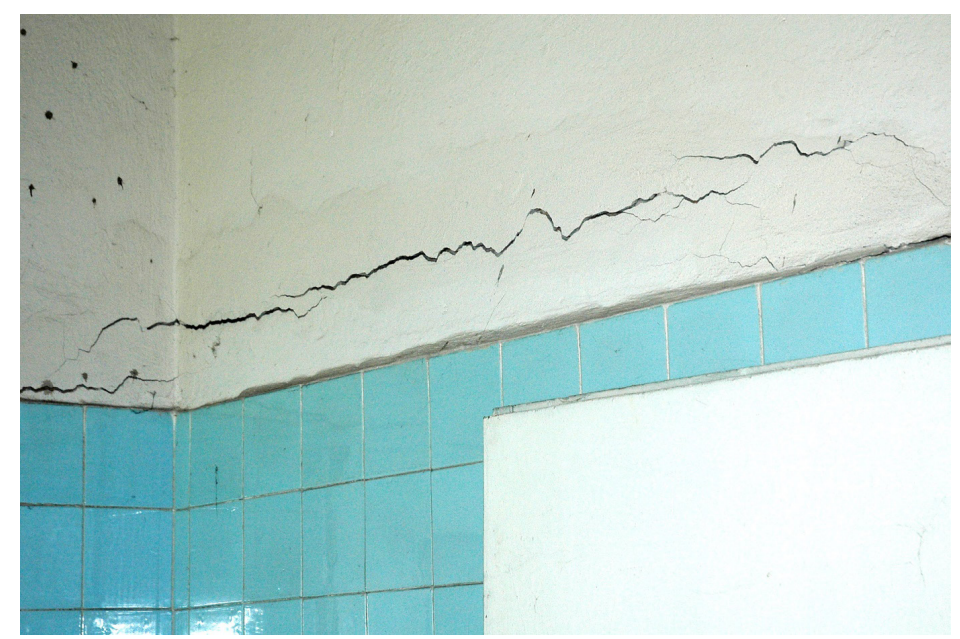

Fig. 10. Horizontal cracks in masonry partitions in basements. Source: author 
On the first floor of segment 1 , a crack was observed at the junction between the west gable wall and the internal brick longitudinal wall. This wall is approximately $3 \mathrm{~m}$ long and the other end of the wall remains free. The extent of the crack ranged from $0 \mathrm{~mm}$ bottom to approximately $8 \mathrm{~mm}$ top. This wall was placed directly on one of the precast reinforced concrete beams of the basement floor (spanning $6 \mathrm{~m}$ ). As there is no wall (longitudinal or transverse) below, the floor beam deflected. The wall resting on it fell down with it, the free end of which coincides with the middle of the beam's span. This caused a crack to appear at the junction of the masonry with the gable wall, with its opening increasing upwards

Similar cracks in appearance and origin are found at the junction of the masonry partition walls of the second storey with the western gable wall (e.g. Fig. 11). The sagging of both ceilings is additionally favoured by their structure. The longitudinally aligned prefabricated elements can work independently to a large extent ("buckling").

Scratches, small cracks and chipped plaster on the joints of prefabricated reinforced concrete elements of the above-ground walls are a separate group. The described damages are characteristic for buildings erected in the skeleton technology, with rigid cladding and are common in similar buildings throughout the country. In this case, the damage to the plaster was additionally increased by rainwater flowing down the façade and leaking from the damaged gutters.

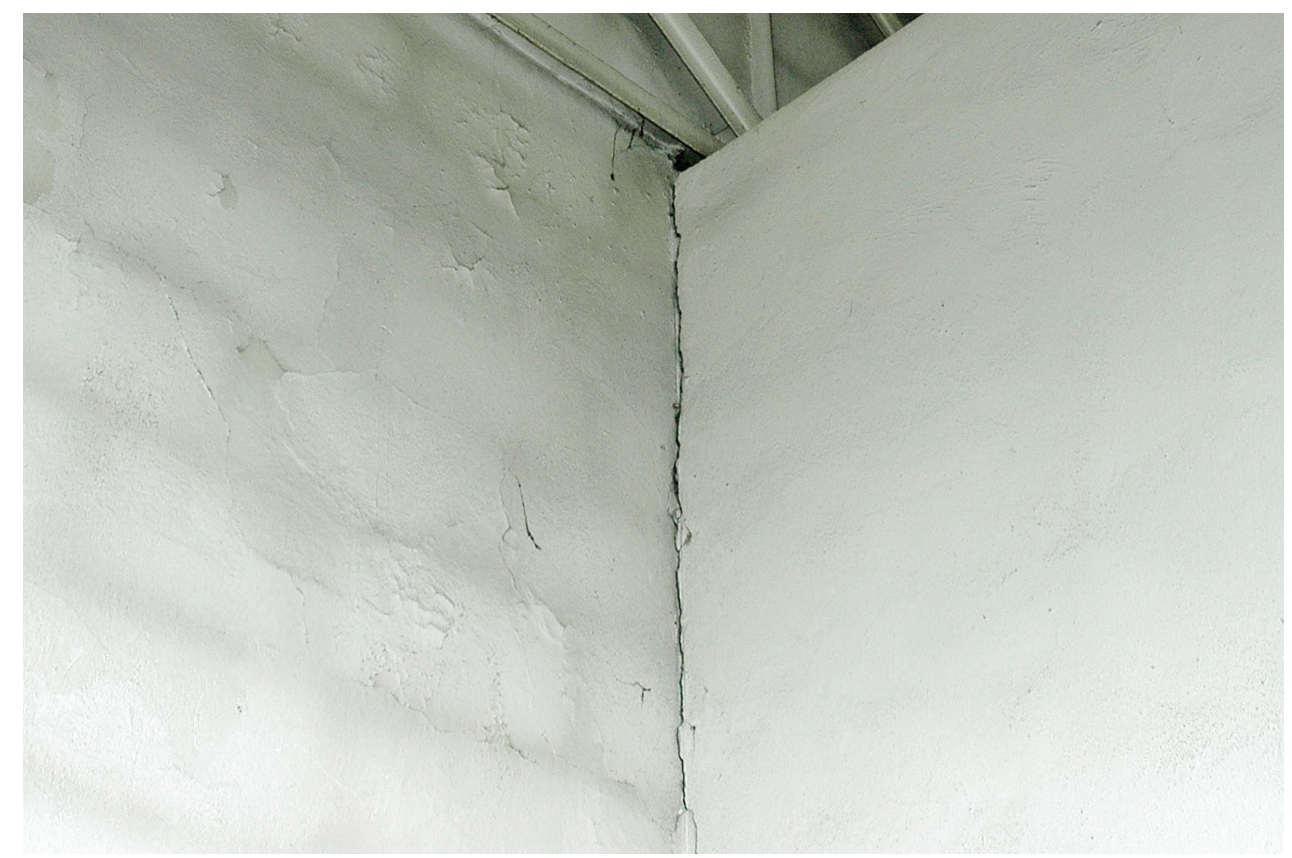

Fig. 11. Cracks at the junction of the masonry partition wall of the second storey with the western gable wall. Source: author 


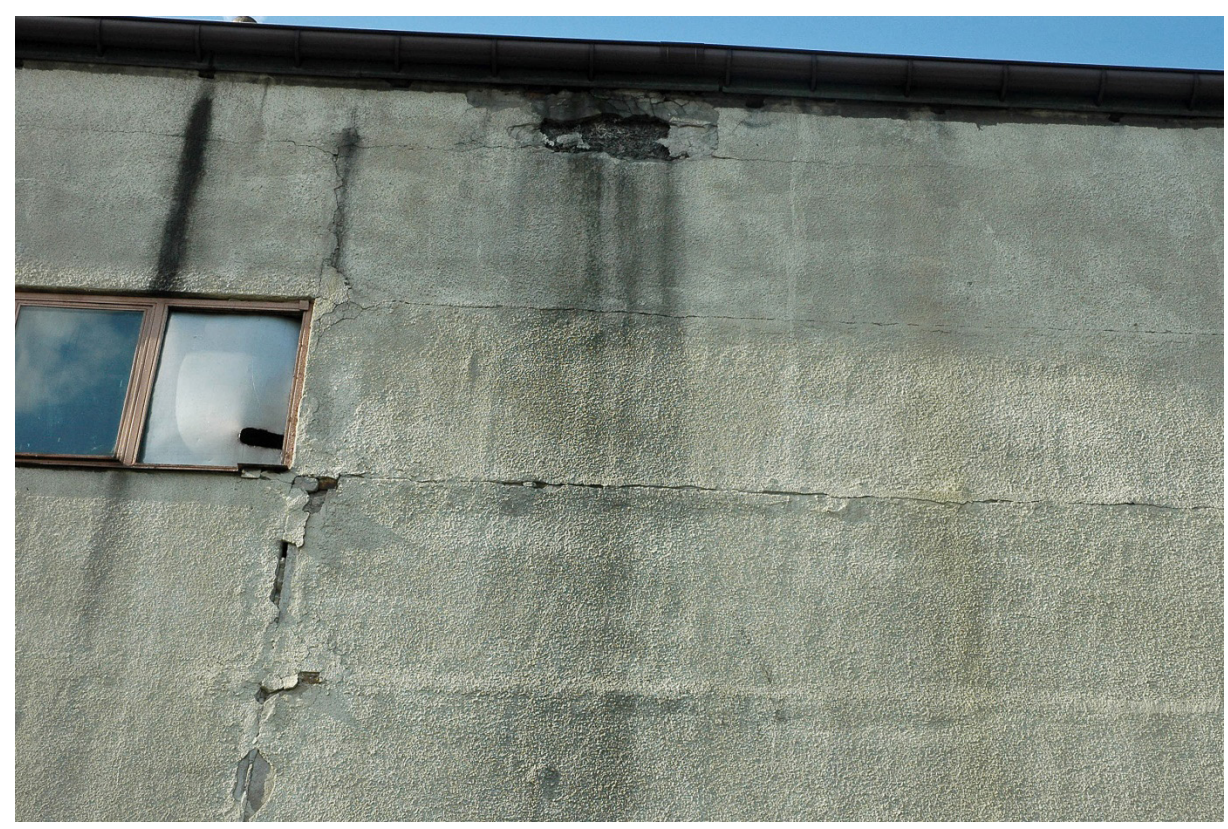

Fig. 12. Western fragment of the northern wall of segment 1 - visible cracks and chipping cracks and chipping of plaster at the joints of prefabricated housing elements and dark damp patches. Source: author

It should be emphasised that no damage to the load-bearing structure of the building was found. All the described damages concern secondary elements and do not pose a threat to the safety of the building. The technical condition of the building was generally assessed as satisfactory.

\subsection{Assessment of mining influences in the building area}

Simultaneously with the structural analysis, work was carried out to determine the maximum extent of mining influence that could affect the building in question [2]. This took into account both the possibility of continuous and discontinuous deformations and paraseismic influences.

The analysis of mining data showed that the maximum values of continuous deformation indicators did not exceed those corresponding to mining site category I. These results were verified on the basis of detailed visual inspections and measurements of dilatation gap dilation. Among the indicators of continuous deformations, the most significant for the analysed building are horizontal deformations and curvature of the terrain. In the case of tensile horizontal deformations (accompanied by convex curvature), we can observe distancing of the building segments from each other, resulting in dilation of dilatation joints. In the case of compressive deformations (concave curvature) the segments move closer to each other, at the same time tightening the dilatation joints. The changes in the dilatation joints, calculated on the assumption of indicators characterising the mining area category I $(\varepsilon=1.5 \mathrm{~mm} / \mathrm{m}$ and $R=20 \mathrm{~km})$ [8], should amount to approximately $\pm 62 \mathrm{~mm}$ on the eastern dilatation and approximately $\pm 46 \mathrm{~mm}$ on the western dilatation. However, detailed visual inspection of both dilatations showed virtually no movement on them. For example, the dilatation joint between reinforced concrete walls 
of the basement, visible in the basement corridor, was bricked up and plastered over several years ago (which is inconsistent with the rules of construction art). The possible appearance of mining influences in this place would have to result either in the creation of a crack of the above-mentioned opening, or in crushing the wall filling the dilatation joint. The visual inspection showed the presence of a crack at the dilatation joint with a delineation of approximately $1 \mathrm{~mm}$ (Fig. 13). This means that since the time of masonry work on the dilatation joint in the building, practically no influence of continuous deformation has appeared.

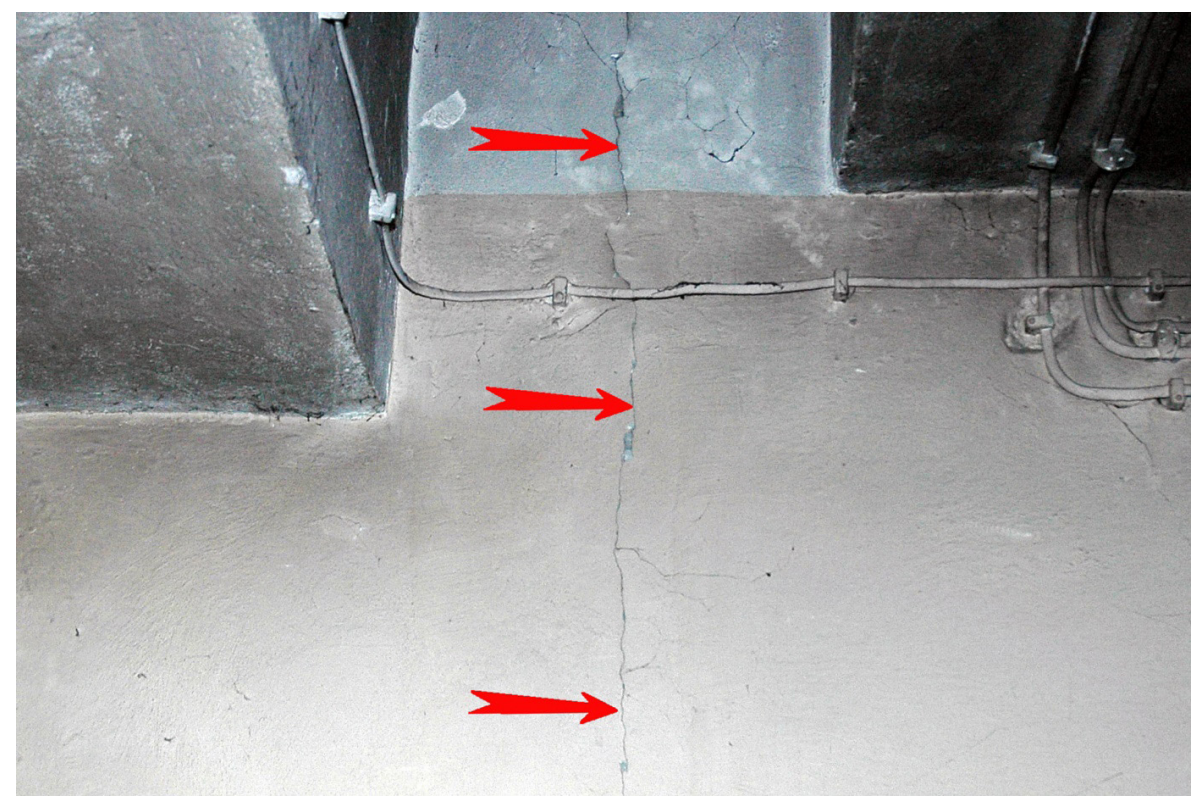

Fig. 13. $1 \mathrm{~mm}$ crack at the bricked up and plastered expansion joint between segments 2 and 3 at ground level. Source: author

Non-continuous deformation usually takes the form of faults or local sinkholes. The latter may be related to the activation of old shallow gobs after former shallow seams exploitation. The formation of a fault or sinkhole under a structure is usually associated with severe damage to the load-bearing structure (e.g. [3], [4]). The damage is caused by significant irregular settlement of the building fragments in relation to its remaining part. The detailed local inspection did not reveal the presence of any damage which could be caused by the occurrence of discontinuous deformations. Therefore, it should be concluded that no discontinuous deformations occurred under the analysed building, especially that they were not observed in the nearest vicinity of the building either

The potential causes of damage to buildings in mining areas also include paraseismic impacts from mining tremors. However, the list of tremors attached to the court file shows that the maximum amplitude of vibration acceleration that the building could experience did not exceed $30 \mathrm{~mm} / \mathrm{s} 2$. Meanwhile, shocks which can cause any damage to buildings are assumed to be those whose accelerations are several times higher (e.g. [5], [8]). This information was additionally confirmed during the interview with the Owner, who did not observe any tremors in his building. Therefore, also mining tremors should be excluded as a potential cause of damage. 
The analysis shows that construction defects were the main cause of damage in this case. There was also a large group of damages characteristic for the applied construction technology, commonly occurring in building structures regardless of their location. On the other hand, the analysis of mining impacts ruled them out as potential causes of damage. Thus, the existence of a cause-and-effect link between the mining plant's activity and the damage to the building in question was excluded. In the pleading, the Owner's crowning argument was that twice before (in 1989 and then in 1993) the same damage had been recognised by the District Mining Damage Commission as mining damage. This proves that wrongful claims were recognised twice and undue compensation was paid. This was done without proper analysis, acting according to the scheme: "since there is damage and the object is located in a mining area, it is mining damage".

\section{Summary and conclusions}

The cases presented in the article are examples of the so-called pseudo-mine damage. As a rule, they look similar to damages caused by mining influences, therefore it is easy to make a suggestion and associate their existence with underground mining exploitation. In both cases the main cause of damage was construction defects. There was also a large group of damages characteristic for the applied construction technology, commonly occurring in buildings regardless of their location. On the other hand, the analysis of mining impacts excluded them as potential causes of damage. Thus it was demonstrated that there was no causal link between the mining plant's activity and the damage, and the court cases ended with the dismissal of unjustified claims. It is worth noting that in the second case, exactly the same damage was recognised several years earlier by the Regional Commission for Mining Damages as mining damage, which resulted in wrongful payment of compensation. The Commission acted according to the scheme: "since there is damage and the object is located in a mining area, it is mining damage".

These cases confirm the thesis that the mere picture of damage without professional analysis of construction and mining factors can lead to wrong conclusions and result in unjust rulings.

Fundings: The research and this work was made possible thanks to the AGH Research and Development Grant No. 16.16.150.545.

\section{References}

[1] Piwowarski W., Kocot W., "Analiza oddziaływań deformacyjnych i parasejsmicznych indukowanych działalnością górniczą na obiekt budowlany”, in: International conference: XI Szkoła Geomechaniki 2013, Gliwice-Ustroń, 2013.

[2] Kocot W., Piwowarski W., Przyktad niewłaściwej oceny przyczyn powstania uszkodzeń budynku na terenach górniczych, in: Conference materials of the scientific and technical conference „X Dni Miernictwa Górniczego i Ochrony Terenów Górniczych", Kraków 2009.

[3] Barycz S., Kocot W., Wodyński A., "O uszkodzeniach budynków spowodowanych nieciągłymi deformacjami terenu”, Przeglad Górniczy, no. 12/1999, Katowice.

[4] Barycz S., Firek K., Kocot W., Wodyński A., "Analiza bezpieczeństwa dwóch budynków zagrożonych reaktywacją starych zrobów górniczych", in: IX Scientific and Technical Conference „, Renovation Problems in General Construction and Historical Buildings”, Wrocław - Szklarska Poręba 2000. 
[5] Muszyński L., "Klasyfikacja dynamicznej odporności budynków”, Przegląd Górniczy, no. 1/1993, Katowice.

[6] Cianciara A., Cianciara B., Isakow Z., "Problematyka opisu oddziaływania drgań, wywołanych wstrząsami, na powierzchnię Ziemi”, Mechanizacja i Automatyzacja Górnictwa, R43 no. 2/2005, Katowice.

[7] Gibowicz S., Mechanizm ognisk wstrząsów górniczych. Warszawa-Łódź: PWN, 1989.

[8] Kwiatek J., Ochrona obiektów budowlanych na terenach górniczych. Katowice: Central Mining Institute, 1997.

[9] Act of June 9, 2011 - Geological and Mining Law (Journal of Laws of 2011, No. 163, item 981), uniform text, Journal of Laws No. of 2020, item 1064.

[10] Kocowski T., Małecki W., Wojtulek M., Prawo geologiczne i górnicze. Warszawa: C.H. Beck, series: Podręczniki prawnicze, 2020. 
